\title{
EFFICIENCY ANALYSIS OF INDUCTION AIR HEATER AND INVESTIGATION OF DISTRIBUTION OF ENERGY LOSSES
}

\author{
Umit Unver
}

Original scientific paper In this study, an induction air heater prototype that is designed to supply hygienic air was analysed. The purpose of this paper is to determine the distribution of energy losses and investigate the effects of inducer discs on the thermal efficiency of the prototype. The analysis was carried out by applying the 1st Law of Thermodynamics. In the study, the natural convection and radiation losses, the discharge losses and the losses due to kinetic energy were calculated and presented. The maximum thermal efficiency was calculated to be $29,9 \%$ without discs. It was seen that, to ensure the competitiveness of the induction air heater among other air heaters, the thermal efficiency can be boosted up to $90 \%$ with appropriate insulation and construction. It was seen that utilizing the discs decreased the efficiency and the total energy loss was reduced as the number of discs was decreased.

Keywords: air heating by induction; energy efficiency enhancement; First Law efficiency; induction fluid heater; induction heating; thermal efficiency

Analiza učinkovitosti indukcijskog grijača zraka i ispitivanje raspodjele gubitaka energije

Izvorni znanstveni članak

U ovom se radu analizira prototip indukcijskog grijača zraka konstruiranog za dovod higijenskog zraka. Cilj je rada odrediti raspodjelu gubitaka energije $\mathrm{i}$ ispitati učinke diskova na toplinsku učinkovitost prototipa. Analiza je provedena primjenom prvog zakona termodinamike. U radu su izračunati i prezentirani gubici zbog prirodne konvekcije i zračenja, gubici ispuštanja i gubici zbog kinetičke energije. Izračunato je da je maksimalna toplinska učinkovitost $29,9 \%$ bez diskova. Ustanovljeno je da, kako bi se osigurala konkurentnost indukcijskih grijača zraka u odnosu na druge grijače, toplinska učinkovitost se može povećati do 90 \% odgovarajućom izolacijom i konstrukcijom. Ustanovljeno je da primjena diskova smanjuje učinkovitost i ukupni se gubitak energije smanjio smanjenjem broja diskova.

Ključne riječi: indukcijski grijač fluida; povećanje energetske učinkovitosti; toplinska učinkovitost; učinkovitost Prvog zakona; zagrijavanje indukcijom; zagrijavanje zraka indukcijom

\section{Introduction}

The history of induction heating began with the observation of unwanted heat in the surrounding magnetic materials. The first use was for smelting in 1916 and it began to be used for hardening after 1930's. The earliest scientific studies about induction heat treatment were published in the 1940's [1].

Induction heaters were developed together with their associated electronic devices. Today they are widely preferred in industry for pre-heating, post heating, melting, forging, sealing, fastening and the cementation of metals [2]. Induction furnace manufacturers also state that the equipment is used in various applications such as hardening, tempering, soldering, normalization, rectification, power production for plasma applications, food packing, shrinking, glass and wool fiberization, in line heat treatment and the hardening of large rings [3]. Scientific studies about induction heaters were increased because of this industry preference.

In the literature, there are numerous papers about the automatic control of induction furnaces [4] and the microstructure of the heat-treated metals by induction furnaces $[5,6]$. Furthermore, there are numerous studies about a variety of fields such as, polymerization of adhesives [2], production and sterilization of surgical equipment [7], Physical Vapor Deposition (PVD) coating [8], asphalt heating [9], heavy oil/bitumen heating [10], non-catalytic oxidation of natural gas [11], heating of metal catalysts for exhaust gas cleaning [12], two phase heat transfer [13] and even more the removal of water droplets from a mirror surface [14]. Scientists are searching for effective uses of induction furnaces and the means to develop them further. The main reason for this interest, as well as giving reliable operation regimes, high efficiency, clean operation, compact design and lightweight construction, is that there is a consensus about the reliability of these furnaces because of their fast response to temperature changes, and their ability to provide precise, stable and contactless thermal control $[12,13,15,16$ and 17]. It is stated that induction heating furnaces are advantageous because of their very fast heating capabilities and excellent automation opportunities [8, 18], and induction heating systems shorten the cycle period because of the heat flow density which allows partial hardening with low costs [19]. Moreover, induction systems provide uniform heat distribution, the opportunity to create large heat surfaces, lack of erosion and thermal deformation and they also have the additional advantage of immediately ensuring the desired temperature in pipelines [20, 21]. Today induction-heating systems are even preferred in stagnant fluid heating in domestic cookers. The studies on domestic cookers focus on various topics including the electrical structure of the heaters [22], the alloys used in kitchen appliances [23] and their heating efficiency [24, 25].

In this study, a continuous flow induction fluid heater was analysed. Similar studies were focused on the electrical structure of the system and the preference for water as the working fluid [26, 27]. Although there are a limited number of papers that discuss gas heating $[16,17]$ or superheated steam generation [7], the researches which examined the energy distribution of the induction air heating system were deemed to be insufficient. With the introduced system, several issues were planned to be solved by utilizing induction air heaters instead of the conventional resistant heaters or fuel fired heaters, such as 
hazards, environmental pollution, corrosion, growth of bacteria and/or viruses in the heater shell, short life span, maintenance necessity, temperature fluctuations.

In this study, magnitude and rate of thermal losses were investigated for hygienic induction air heaters that are designed for fresh fruit and vegetable drying. The energy distribution of the system was analysed and the thermal efficiency was calculated. An action plan was recommended for further studies to increase the efficiency.

\section{Method \\ 2.1 Induction principle of the fluid heater}

The induction principle of the heater: when an electric current passes from a conductive winding around a shell, according to the right hand rule, a magnetic field occurs which is perpendicular to the current. If there is a magnetic material in the magnetic field another current is induced in the material that is called eddy currents [28]. These eddy currents will cause:

$P_{\mathrm{el}}=I \cdot V \cdot P F$

of electric power which will be converted to thermal power [4]. In this equation, $V$ is voltage (V), $I$ is current (A) and $P F$ is the power ratio.

In induction heating systems the electric current in cylindrical magnetic logs reduces from the wall towards the centre and so does the heat flux [29]. In the analysis, a ferromagnetic tube with an outer diameter of $140 \mathrm{~mm}$ and a wall thickness of $5 \mathrm{~mm}$ was used. It was reported that the temperature difference between the outer surface and the inner surface is negligible in a hollow bar that is moving in an induction heater [30]. The wall thickness of the heater that was used in this paper is less than the tube mentioned in [30]. In this study, the steady state conditions were analysed. Thus, when solving the heat transfer problem in cylindrical coordinates, the radial temperature difference was neglected and excluded. A mathematical model of the system was set up like a shell with the heat flux of $\dot{q}_{p}\left(\mathrm{~W} / \mathrm{m}^{2}\right)$.

\subsection{Governing equations}

From the 1st Law of Thermodynamics, the energy balance of thermal system can be written as:

$$
E_{\mathrm{i}}+E_{\text {gen }}-E_{\mathrm{o}}=\mathrm{d} E_{\mathrm{st}} .
$$

In the equation, $E_{\mathrm{i}}(\mathrm{J})$ represents the energy entering the system and $E_{\mathrm{o}}(\mathrm{J})$ represents the energy exiting the system with the fluid flow. In this paper $E_{\text {gen }}(\mathrm{J})$ is considered as the electrical power that is generated in the shell by induction. The heating of a material by the induction principle requires electrical expertise. So the electric analysis was excluded from this study after giving the necessary and basic principles. $\mathrm{d} E_{\mathrm{st}}$ is the stored energy in the system which increases with rising temperature until the system reaches thermal equilibrium. When the system reaches steady state conditions, energy will no longer be stored in the shell; it will either be conducted to the environment or be used by the flowing fluid. In steady state conditions Eq. (2) becomes,

$\mathrm{d} E_{\text {gen }}=\mathrm{d}\left(E_{\text {out }}-E_{\text {in }}\right)$

Considering that the induction system is a heater and no other work will be done to or against the system and using the definition of power as the variation of utilized energy in a unit time, the electric power consumed from the grid can be calculated as

$P_{\mathrm{el}}=\frac{\mathrm{d} E_{\mathrm{gen}}}{\mathrm{d} t}$

Here $P_{\text {el }}$ was calculated from Eq. (1). The energy that is entering to the control volume cannot be converted to the heat. In this situation introducing induction efficiency $\left(\eta_{\text {ind }}\right)$ the energy that is induced in the shell can be calculated as;

$E_{\mathrm{sh}}=E_{\mathrm{gen}} \cdot \eta_{\text {ind }}$,

and in unit time;

$P_{\mathrm{sh}}=P_{\mathrm{el}} \cdot \eta_{\text {ind }} \cdot$

Here $\eta_{\text {ind }}$ indicates the induction efficiency, which depends on the type and electromagnetic characteristics of the cable, the number of windings, frequency and the system geometry [24]. Because the scope of this study covers thermal efficiency and the determination of the parameters affecting the thermal efficiency, the induction efficiency value of 0,95 given by the manufacturer was used. The ratio of this induction efficiency in thermal efficiency was also given.

However, the induction losses are not the only losses in the system. A portion of the energy induced in the shell can be transferred to the fluid. The rest of the energy will be conducted to the environment by heat transfer or other losses. Considering the total losses the energy that is transferred from the shell to the fluid can be described as

$P_{\mathrm{fl}}=P_{\mathrm{el}} \cdot \eta_{\mathrm{I}}$

Here $P_{\mathrm{fl}}$ is the thermal power that is transferred to the fluid and $\eta_{\mathrm{I}}$ is the first law efficiency. The efficiency can easily be calculated by the ratio of the thermal power transferred to the fluid to electric power. If we want to enhance the thermal efficiency, we need to know where and how the electric power is consumed or lost. Thus, the detection and prevention of energy losses is an important issue and should be calculated individually.

Until recently, water was the preferred working fluid. But in this study, the working fluid is air. Because of this efficiencies and losses were calculated using the ideal gas approach. For a better understanding of energy losses, opening the Eq. (3) for steady flow process:

$$
\dot{Q}+\dot{m}\left(h+\frac{v^{2}}{2}+g z\right)_{\mathrm{i}}+\dot{W}-\Delta P_{\mathrm{DL}}=\dot{m}\left(h+\frac{v^{2}}{2}+g z\right)_{\mathrm{o}}
$$


Here $z$ is the potential difference at the inlet and exit, which is negligible. $v$ is the velocity of the air at the inlet and at the exit, $h$ is the enthalpy and $P_{\mathrm{DL}}$ is the power loss due to discharge. Except for electrical work there is no work done to or against the system and because of this the induction heating was modelled as thermal power generation like $\dot{W}=\dot{Q}_{\text {gen }}$. The first term in the equation

$(\dot{Q})$ was accepted as the heat transferred to the environment in a unit time $\left(-P_{\mathrm{ht}}\right)$. This thermal power is transferred from the hot system surface to the cold environment by radiation and natural convection.

$-P_{\mathrm{ht}}=P_{\mathrm{rad}}+P_{\mathrm{fc}}$.

The minus represents the direction of the power transfer. In the Eq. (8), $P_{\mathrm{rad}}$ is the heat loss by thermal radiation.

$P_{\mathrm{rad}}=\sigma \cdot \varepsilon \cdot A_{\mathrm{ht}} \cdot\left(T_{\mathrm{sh}, \mathrm{o}}^{4}-T_{\infty}^{4}\right)$,

where $\sigma=5,67 \times 10^{-8}\left(\mathrm{~W} / \mathrm{m}^{2} \mathrm{~K}^{4}\right)$ is the Stefan-Boltzman constant, $\varepsilon \approx 0,8$ emissivity for grey steel, $A_{\mathrm{ht}}\left(\mathrm{m}^{2}\right)$ is the heat transfer surface area, $T_{\mathrm{sh}, \mathrm{o}}(\mathrm{K})$ is the outer surface temperature of the shell, and $T_{\infty}(\mathrm{K})$ is the ambient temperature. The natural convection loss that was used in Eq. (8) as can be calculated via the following equation [31]

$P_{\mathrm{fc}}=\left\{0,6+\frac{0,387 \cdot R a^{\frac{1}{6}}}{\left[1+\left(\frac{0,559}{P r}\right)^{\frac{9}{16}}\right]^{\frac{8}{27}}}\right\}^{2} \frac{k}{D} A_{\mathrm{ht}}\left(T_{\mathrm{sh}, \mathrm{o}}-T_{\infty}\right)$,

where the conduction coefficient of the air $(k)$, kinematic viscosity $(v)$ in Eq. (11), Prandtl number $(P r)$ were taken from thermodynamic tables at $T_{\mathrm{f}}=\left(T_{\mathrm{sh}, \mathrm{o}}-T_{\infty}\right) / 2$ film temperature. $\mathrm{D}$ is the diameter of the shell with windings and $\beta=1 / T_{\mathrm{f}}(1 / \mathrm{K})$. Ra is the Rayleigh number that can be calculated by multiplication of Grashof number $(G r)$ by $\operatorname{Pr}[32]$

$R a=G r \cdot \operatorname{Pr}=\frac{g \cdot \beta \cdot\left(T_{\mathrm{sh}, \mathrm{o}}-T_{\infty}\right) \cdot D^{3}}{v^{2}} \operatorname{Pr}$.

The thermal power, which is generated in the system, increases the temperature of the fluid. This increment changes pressure and density. In Eq. (7), the heat transfer to the fluid can be calculated by

$P_{\mathrm{fl}}=\dot{m} \mathrm{~d} h=\dot{m}\left(h_{\mathrm{o}}-h_{\mathrm{i}}\right)$.

The losses due to kinetic energy variation, which is caused by reduction of the air density, can be described as
$\Delta P_{\mathrm{KE}}=\dot{m} \cdot\left(\frac{V_{\mathrm{o}}^{2}-V_{\mathrm{i}}^{2}}{2}\right)$

To determine the kinetic energy losses, first the inlet velocity should be calculated. The inlet velocity of a steady process can be calculated from the mass balance equation

$\dot{m}_{\mathrm{i}}=\dot{m}_{\mathrm{o}}$,

$(\rho V A)_{\mathrm{i}}=(\rho V A)_{\mathrm{o}}$.

For the experimental rig that was used the inlet and the outlet sections were equal. Thus from the Eq. (14b), inlet velocity can be calculated as

$V_{\mathrm{i}}=\frac{\rho_{\mathrm{o}}}{\rho_{\mathrm{i}}} V_{\mathrm{o}}$.

Here $\rho_{\mathrm{o}} / \rho_{\mathrm{i}}$ is the ratio of the density of the inlet air to the density of the outlet air. Re-arranging the given equations Eq. (7) yields

$P_{\mathrm{fl}}=P_{\mathrm{gen}}-P_{\mathrm{ht}}-\Delta P_{\mathrm{KE}}-\Delta P_{\mathrm{DL}}$

In this equation the first four statements can be calculated from the measurements performed in the experiments but the last term discharge losses $\left(\Delta P_{\mathrm{DL}}\right)$ should be calculated individually in order to determine the overall energy losses. From the Eq. (16) losses of friction and discharge can be calculated as [32]

$\Delta P_{\mathrm{DL}}=P_{\mathrm{gen}}--P_{\mathrm{fl}}-P_{\mathrm{ht}}-\Delta P_{\mathrm{KE}}=\dot{m}\left\{f \frac{L}{D}+C_{\mathrm{D}}\right\} \frac{V^{2}}{2}$

can be written. Here, $\left\{\dot{m} f \frac{L}{D} \frac{V^{2}}{2}\right\}$ represents the friction losses in a tube. The friction losses were calculated and it was seen that the total magnitude was less than $0,1 \%$ of the electric power so it was neglected. In this case rearranging Eq. (17) the discharge coefficient can be calculated as

$C_{\mathrm{D}}=\frac{2\left(P_{\mathrm{gen}}-P_{\mathrm{fl}}-P_{\mathrm{ht}}-\Delta P_{\mathrm{KE}}\right)}{\dot{m} \cdot V^{2}}$.

This coefficient is important for explaining the effect of the number of discs and the flow parameters on the thermal efficiency. Finally, we can determine

$P_{\Sigma \mathrm{L}}=P_{\mathrm{ht}}+\Delta P_{\mathrm{KE}}+\Delta P_{\mathrm{DL}}$

for the overall losses and

$\eta_{\mathrm{I}}=1-\frac{P_{\mathrm{\Sigma L}}}{P_{\mathrm{el}}}=\frac{P_{\mathrm{fl}}}{P_{\mathrm{el}}}$ 
for the thermal efficiency. This efficiency expression gives information about the recoverable energy using appropriate insulation and construction by providing insight into thermal power losses, discharge losses and the losses due to kinetic energy variation.

\subsection{The experiments}

A 3-D Model of the analysed induction fluid heater is given in Fig. 1. The shell length of the induction heater was $450 \mathrm{~mm}$ and was made of ST52 steel carbon steel. At each side of the shell, there are two ST-52 carbon steel caps. The diameter of the caps was $140 \mathrm{~mm}$ and the thickness was $10 \mathrm{~mm}$. Each cap is compressed by double nuts for leak proofing using a long stud bolt that passes through the centre of the discs and the shell. The induction fluid heater was constructed to allow the placing of any desired number of inducer discs with a diameter of $129,5 \mathrm{~mm}$ and a thickness of $5 \mathrm{~mm}$. The discs are placed vertically to the magnetic field with the aim of inducing a magnetic flux in themselves so that the resultant Eddy currents would heat the discs and the discs will heat the fluid. The discs are designed to be assembled at a desired location on the stud bolt with nuts. The discs were laser cut with a $40 \times 6 \mathrm{~mm}$ rectangular flow slit. The aim of the flow slit is to provide a staggered fluid flow in the shell. In this way enhancing the area of contact between the fluid and heater surfaces was planned.

There are 361 windings placed tightly around the shell using $\varnothing 4 \mathrm{~mm} \mathrm{E}_{\mathrm{Cu}}$ cable. To avoid vibration and reduction of induction efficiency the windings were tightly wrapped on the shell. The outer diameter of the windings was measured at $145 \mathrm{~mm}$ and this dimension was used in the natural convection and radiation calculations. The diameter of the inlet and outlet sections of the system was $28 \mathrm{~mm}$.

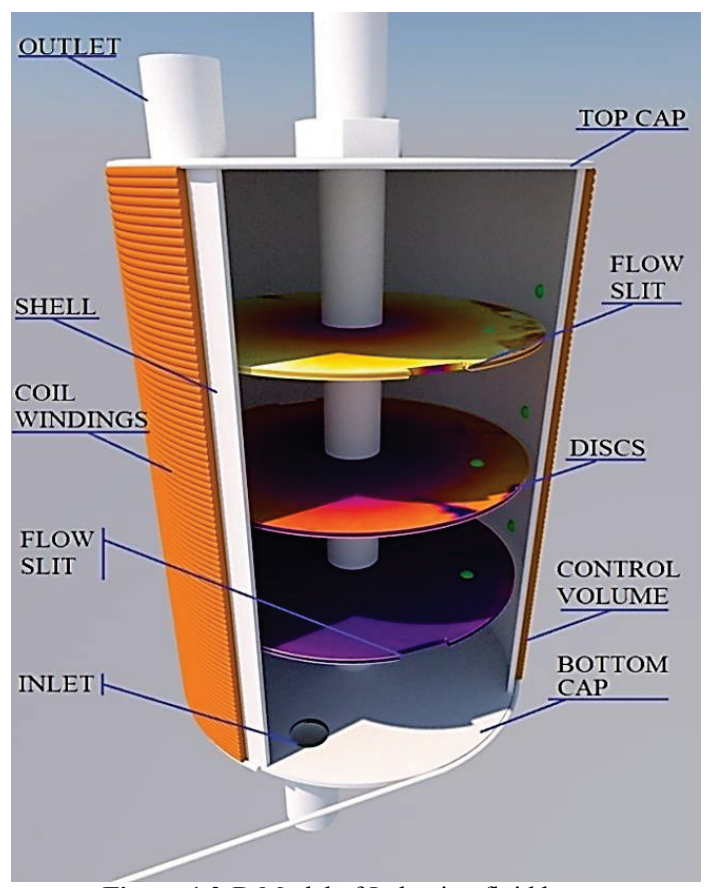

Figure $13-D$ Model of Induction fluid heater

The effect of the inducer discs on thermal energy efficiency was analysed in the experiments. In the disc experiments the electrical power was set to $P_{\mathrm{el}}=1,4 \mathrm{~kW}$ $\left(q=7,077 \mathrm{~kW} / \mathrm{m}^{2}\right.$ heat flux on the shell) while in the discless experiments it was set to $P_{\mathrm{el}}=1,2 \mathrm{~kW}(q=6,066$ $\mathrm{kW} / \mathrm{m}^{2}$ heat flux on the shell). The electrical power and fluid flow were started simultaneously and all measurements were taken instantaneously and simultaneously every minute. Beside the measuring points that are given in [33], disc temperature measurements and temperature distribution measurements of side and caps were determined using thermal camera views. Additional information about the protocol of the experiments is given below.

Four experiment groups were performed for the analysis. The first group was 5 disc-experiments. In these experiments, five discs placed equidistant to each other and to the caps were used. The inlet and outlet temperatures, the outer surface temperature distribution of the shell and the outlet velocity of the fluid were measured. The second group was three disc-experiments. In this experiment the inlet and outlet temperatures, the outer surface temperature distribution of the shell, the outlet velocity of the fluid and the temperature distribution of discs were measured. In the 2-disc and discless experiments the inlet and outlet temperatures, outer surface temperature distribution of the shell and outlet velocity of fluid was measured. In all experiments, the air was supplied from and discharged to workshop environment.

\subsection{Uncertainty analysis}

The difference between the inlet and outlet temperature remains constant in the steady state. In the experiments, the parameters were measured every minute until a steady-state condition was achieved but during the calculations, the latest measurements obtained after the steady state condition was achieved were used. The response time of thermal systems is generally long, so the steady state condition was assumed as

$$
\Delta T_{\varepsilon}=\frac{\left(T_{i-1}-T_{i-2}\right)+\left(T_{i}-T_{i-1}\right)+\left(T_{i+1}-T_{i}\right)+\left(T_{i+2}-T_{i+1}\right)}{4}<0,3{ }^{\circ} \mathrm{C} .
$$

The effect of $0,3{ }^{\circ} \mathrm{C}$ on the thermal efficiency was calculated as $\pm 0,17 \%$.

The range and accuracy of the measurement devices are given in Tab. 1. For all experiment groups, the random uncertainties were calculated using the following equation [34]

$$
W_{Y}=\left[\sum_{i=1}^{n}\left(\frac{\delta Y}{\delta x_{i}} w_{i}\right)^{2}\right]^{\frac{1}{2}}
$$

The results of uncertainty analysis for thermal efficiency and the parameters that were used in calculating the thermal efficiency are given in Tab. 4 .

\section{Results and discussion}

In the three disc-experiments four thermocouples were soldered starting $1 \mathrm{~mm}$ inside the outer edge and the 
temperatures of the discs were measured along their radius. A 3-D illustration of the temperature distribution of the discs with the measured values is given in Fig. 2. The measurements were performed after satisfying the $T_{\delta}$ $<0,3{ }^{\circ} \mathrm{C}$ steady state condition. In the illustration the colour scale and colours of the thermal view of another induction heated aluminium disc was used. For easy identification, the discs were numbered in order of entrance to exit. As it can be seen in the figure, the temperature of the first disc is very close to the temperature of the inlet air. The temperature of the second disc was measured at $25 \div 30{ }^{\circ} \mathrm{C}$, while that of the third was $25 \div 32{ }^{\circ} \mathrm{C}$. Although the distance between the first and second disc was the same as between the second and the third disc, there is a big difference between the temperatures of the first two discs but not between the last two. This means that the first disc is cooled by the inlet air and it is not heated enough by induction. The temperature of the second disc, where the cooling effect of inlet air is not seen, is higher than the first disc. The temperature difference of third and second disc is below 2 ${ }^{\circ} \mathrm{C}$. Induction system maximum heating corresponds to the midpoint of the windings where the maximum Eddy currents emerge [29]. Reconsidering the temperature distribution of the discs with this information and by measuring the highest temperatures from the nearest thermocouple to the edge the higher temperature of the second disc can be understood. Moreover, the measured temperature over all the discs decreased towards the centre. The highest temperature was measured on the third disc because there is no such cooling effect at its location as there is in the first and the second discs. Thus, with the thermal energy convection by the working fluid, third disc was the hottest.

Table 1 Measurements and instrument specifications

\begin{tabular}{|l|l|l|c|c|}
\hline & \multicolumn{1}{|c|}{ Item } & \multicolumn{1}{|c|}{ Instrument } & Range & Accuracy \\
\hline 1 & $\begin{array}{l}\text { Temperature measurement at inlet and outlet. } \\
\text { Temperature distribution measurement inside shell and } \\
\text { discs. }\end{array}$ & $\begin{array}{l}\text { Multi-channel thermometer with } \mathrm{K} \\
\text { type thermocouple. Data Logger. }\end{array}$ & $\begin{array}{c}-100 \text { to } \\
1300^{\circ} \mathrm{C}\end{array}$ & $\begin{array}{c} \pm(0,1 \% \text { reading }+ \\
\left.0,7^{\circ} \mathrm{C}\right)\end{array}$ \\
\hline 2 & Temperature distribution measurement of side and caps & Thermal Camera & $\begin{array}{c}0 \text { to }+350 \\
{ }^{\circ} \mathrm{C}\end{array}$ & $\begin{array}{c} \pm 2{ }^{\circ} \mathrm{C}, \pm 2 \% \text { of } \\
\text { measured value }\end{array}$ \\
\hline 3 & Velocity measurement at outlet & Hot-Wire Anemometer & $\begin{array}{c}0 \text { to } 20 \\
\mathrm{~m} / \mathrm{s}\end{array}$ & $\begin{array}{c} \pm 0,3 \mathrm{~m} / \mathrm{s} \pm 5 \% \text { of } \\
\text { measured value }\end{array}$ \\
\hline
\end{tabular}

Table 2 The results of the experiments

\begin{tabular}{|c|c|c|c|c|c|}
\hline \multirow{2}{*}{ Data } & \multirow{2}{*}{ Units } & \multicolumn{4}{|c|}{ Number of Discs } \\
\cline { 3 - 6 } & & 5 DISC & 3 DISC & 2 DISC & Discless \\
\hline$\dot{m} \times 10^{3}$ & $\mathrm{~kg} / \mathrm{s}$ & 3,55 & 4,58 & 5,31 & 6,36 \\
\hline$t$ & $\mathrm{~s}$ & 1800 & 3600 & 2400 & 2400 \\
\hline$\dot{q}$ & $\mathrm{~W} / \mathrm{m}^{2}$ & 7077,14 & 7077,14 & 7077,14 & 6066,12 \\
\hline$T_{\infty}$ & ${ }^{\circ} \mathrm{C}$ & 9,7 & 8,2 & 9,3 & 6,5 \\
\hline$T_{\mathrm{o}}$ & ${ }^{\circ} \mathrm{C}$ & 72,81 & 70,30 & 70,50 & 61,10 \\
\hline$T_{\mathrm{sh}, \mathrm{i}}$ & ${ }^{\circ} \mathrm{C}$ & 161,0 & 144,4 & 139,5 & 125,1 \\
\hline$T_{\mathrm{sh}, \mathrm{o}}$ & ${ }^{\circ} \mathrm{C}$ & 96,1 & 89,6 & 85,8 & 80,1 \\
\hline$\Delta h$ & $\mathrm{~kJ} / \mathrm{kg}$ & 63,54 & 62,53 & 61,63 & 54,98 \\
\hline$V_{\mathrm{fl}, \mathrm{i}}$ & $\mathrm{m} / \mathrm{s}$ & 4,73 & 6,12 & 7,13 & 8,70 \\
\hline$V_{\mathrm{sh}, \mathrm{m}}$ & $\mathrm{m} / \mathrm{s}$ & 0,27 & 0,34 & 0,40 & 0,48 \\
\hline$V_{\mathrm{fl}, \mathrm{o}}$ & $\mathrm{m} / \mathrm{s}$ & 5,78 & 7,47 & 8,66 & 10,37 \\
\hline
\end{tabular}

However, even the highest temperature of the third disc is far from the temperature of the shell itself where the surface temperatures were measured over $100{ }^{\circ} \mathrm{C}$.

In Fig. 3 the thermal camera view of the 3-disc experiments is given. It is seen that the thermocouple measurements at the inner surface and the thermal camera measurements on the cap are $124,5{ }^{\circ} \mathrm{C}$ and $125{ }^{\circ} \mathrm{C}$ respectively. From Fig. 3 it was seen that the outer surface temperature is about $90{ }^{\circ} \mathrm{C}$ that shows that the windings act somewhat like insulation but not effectively. Another important finding is that although the inner surface temperature reaches $125{ }^{\circ} \mathrm{C}$ the discs temperature cannot exceed $33{ }^{\circ} \mathrm{C}$. This is because in induction systems, the maximum heating takes place at the place nearest to the coil and decreases exponentially with the distance from the coil and $86 \%$ of the heating emerges at the nearest location [36]. This proves a significant fact that is the discs are not heated by induction since the shell induces the magnetic flux on itself and this causes the heating of the shell but not the discs. The discs are placed in the shell with $0,25 \mathrm{~mm}$ peripheral gap that results in no heat being conducted from the shell to the discs because of thermal contact resistance. Moreover, it is observed that the working fluid was heated by convection where it contacts the shell and cooled by the discs where it contacts the discs. The working fluid carried the thermal energy from shell to the discs.

Essentially, the purpose of a fluid heater is to heat the fluid. Thus, it is not important whether the Eddy currents are induced in the shell or the discs. The discs affect the system as a discharge resistor instead of an inducer component; therefore removing the discs from the system was proposed. In this way, some of the energy that is consumed by discs is thought to be recovered by shell and the thermal efficiency is enhanced. Removing the discs also helps to shorten the transient condition time. All these reasons led to repeating the experiments by decreasing the number of the discs and the results are given in Tab. 2. It can be seen from Tab. 2 that the exit velocity and accordingly the mass flow rate decreases with an increasing number of discs. Decreasing the exit velocity, by means of high discharge losses, causes a longer duration for flowing of the fluid that has a positive influence on the exit temperature. Note that, higher exit temperature does not lead to a higher thermal efficiency; it is the result of increasing flow duration because of the discharge losses. The effect of velocity on the thermal efficiency should be considered carefully because the heat transfer increases with the increasing flow rate and that enhances the heat transfer from shell to the fluid. This results in a lower temperature at the inner surface of the shell and at the outer surface of the windings. Thus, thermal radiation from the outer surface of the windings decreases.

In Tab. 2 the variation of the duration of the steady state condition also warrants attention. Mainly due to the 
repeating of the experiment without allowing $T_{\mathrm{sh}, \mathrm{i}}$ the inlet temperature of the shell to decrease to the $T_{\infty}$ environment temperature. However, the purpose of this study is to determine the first law efficiency of the induction heating systems. The differential equations given in the method section consider the energy transfer in unit time or the thermal power; thus, the calculations cover the variation of the initial conditions. In addition, the equations were solved for the steady state conditions and that means the results are independent from the initial conditions and the duration of the steady state conditions. Moreover, the temperature measurements of inlet-outlet flows, shell, environment, measurement of velocity, were performed simultaneously. Therefore, the initial temperature of the shell has no negative influence on the solution of the equations except by reducing the duration of the steady state.

The heat transfer losses by radiation and natural convection were calculated using Eq. (9) and Eq. (10). When the disc number was decreased, the heat transfer to fluid increased with the mass flow rates. The surface temperature of the shell was reduced by increasing energy transfer to the fluid, which also reduces the amount of heat losses due to radiation and natural convection. In addition, the reduction of the finite temperature difference between the shell and the fluid has a positive influence on the heat exchange efficiency.

In Tab. 3 the performance results that were calculated with the experimental data are given. Tab. 4 gives the uncertainties that were calculated using Eq. (21). The induction efficiency is taken as 0,95 according to the manufacturer's data. The energy transfer to the shell was calculated individually for each experiment group.

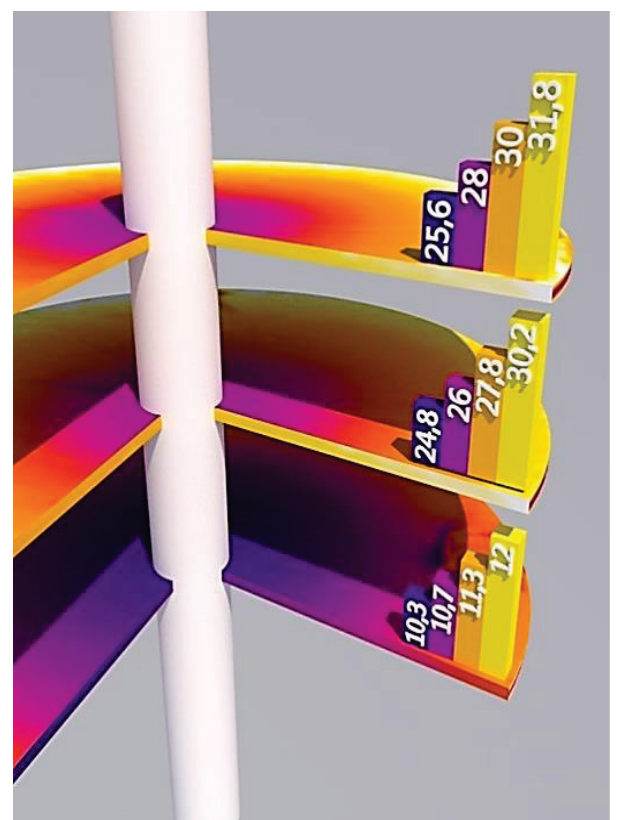

Figure 2 Thermographic temperature distribution on the discs

The losses through the system are the heat transfer losses by means of radiation and natural convection, which was calculated by Eq. (8), the losses due to kinetic energy increment that was calculated by Eq. (13) and the discharge losses. In Tab. 3 lines $8 \mathrm{a}$ and $8 \mathrm{~b}$, it is seen that the heat transfer losses by radiation and natural convection increase by $2,4 \%$ with the number of discs.
The main reason for this is that increasing the disc number reduces the mass flow rate. This means that less energy can be transferred to the fluid. When the total energy that is induced in the shell remains constant, the surface temperature of the shell decreases while the energy transfer to the fluid reduces. The increase of the shell surface temperature results in an increase in heat transfer losses but it should be noted that these losses are recoverable with an appropriate insulation.

In Tab. 3 line 5, the discharge losses are calculated at $50 \%$ in the 5-disc experiments and reduced to $29,9 \%$ when the disc number was decreased. The discharge coefficient CD, which was calculated by Eq. (18) also seems to reduce from about 12 to 1,05 with a decreasing number of discs. This reduction shows that the discharge coefficient is closely related to the number of discs. Because the gap between discs and inner wall of the shell and the flow slit are narrow. The discs prevent the fluid flow, which results in an increment in discharge coefficient. Therefore, as the disc number increase, the discharge coefficient increases and thus the discharge losses increase. The discharge coefficient of the discless experiments is in good agreement with the sharp-edged loss coefficient given in [32] but a value of 1,05 is not acceptable for an induction fluid heater since it results in a minimum of $29,9 \%$ of the energy loss caused by inappropriate charge/discharge construction. With correct inlet/exit geometry and without discs, the discharge coefficient may be reduced to 0,02 and the discharge losses are reduced to $\approx 6,85 \mathrm{~W}(5,71 \%)$. This means that only an appropriate geometry of the inlet and exit sections could enhance the efficiency of the heater by $24 \%$.

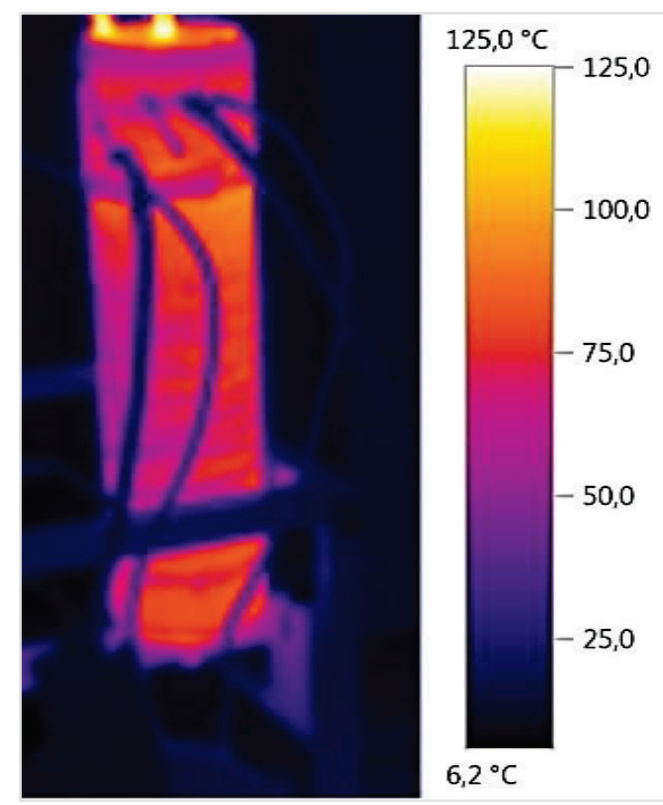

Figure 3 Thermal camera view of the experiment rig

One important result of this study was observing that the improvement of kinetic energy of the fluid due to the increase in exit velocity resulted in a reduction in the thermal efficiency. Because of this, the subject was evaluated under a separate topic. At first glance, the improvement of the kinetic energy does not seem like a loss. However, the purpose of the induction system is not to increase the velocity but to heat the fluid. 
According to the 1st Law of Thermodynamics the same amount of energy that is converted to kinetic energy matches the reduction in thermal energy in the fluid at the exit. The density of the fluid decreases when it is heated. Since the area of inlet and exit sections is unchanged, due to mass balance the exit velocity of the heated fluid is more than the inlet velocity under steady state conditions. If Eq. (15) is rearranged, we can derive a relationship between the desired outlet temperatures from the induction fluid heater vs. the ratio of the inlet diameter to the outlet diameter.

$$
D_{\mathrm{i}}=D_{\mathrm{o}} \sqrt{\frac{\rho_{\mathrm{o}}}{\rho_{\mathrm{i}}}} .
$$

If the design of the induction fluid heater complies with the inlet-outlet cross-sectional diameters, given in Eq. (25), 119,7W of the kinetic energy increase for the discless experiment shown in Tab. 3 line 7 can be added to the fluid. That means $9,9 \%$ of the electrical energy can be recovered by the design of an appropriate geometry.

Table 3 The energy distribution through the induction air heater, thermal efficiencies and the discharge coefficients

\begin{tabular}{|c|c|c|c|c|c|c|c|c|c|c|}
\hline \multirow{2}{*}{ No } & \multirow{2}{*}{ Data } & \multirow{2}{*}{ Unit } & \multicolumn{2}{|c|}{$5 \mathrm{DISC}$} & \multicolumn{2}{|c|}{3 DISC } & \multicolumn{2}{|c|}{2 DISC } & \multicolumn{2}{|c|}{ DISCLESS } \\
\hline & & & Value & $\%$ & Value & $\%$ & Value & $\%$ & Value & $\%$ \\
\hline 1 & $P_{\mathrm{el}}$ & $\mathrm{kW}$ & 1,4 & 100 & 1,4 & 100 & 1,4 & 100 & 1,2 & 100 \\
\hline 2 & $P_{\mathrm{sh}}$ & $\mathrm{kW}$ & 1,33 & 95,0 & 1,33 & 95,0 & 1,33 & 95,0 & 1,2 & 95,0 \\
\hline 3 & $P_{\mathrm{fl}}$ & $\mathrm{kW}$ & 0,2253 & 16,1 & 0,2863 & 20,5 & 0,3274 & 23,4 & 0,3692 & 30,8 \\
\hline 4 & $P_{\Sigma \mathrm{L}}$ & $\mathrm{kW}$ & 1,1747 & 83,9 & 1,1136 & 79,6 & 1,0726 & 76,6 & 0,8308 & 69,2 \\
\hline 5 & $\Delta P_{\mathrm{DL}}$ & $\mathrm{kW}$ & 0,7100 & 50,7 & 0,6549 & 46,8 & 0,6090 & 43,5 & 0,3589 & 29,9 \\
\hline 6 & $P_{\mathrm{L}, \text { ind }}$ & $\mathrm{kW}$ & 0,0700 & 5,0 & 0,0700 & 5,0 & 0,0700 & 5,0 & 0,0600 & 5,0 \\
\hline 7 & $\Delta P_{\mathrm{KE}}$ & $\mathrm{kW}$ & 0,0196 & 1,4 & 0,0418 & 2,9 & 0,0644 & 4,6 & 0,1197 & 9,9 \\
\hline 8 & $P_{\mathrm{ht}}$ & $\mathrm{kW}$ & 0,3752 & 26,8 & 0,3470 & 24,8 & 0,3292 & 23,5 & 0,2923 & 24,4 \\
\hline $8 \mathrm{a}$ & $P_{\mathrm{rad}}$ & $\mathrm{kW}$ & 0,1779 & 12,7 & 0,1575 & 11,3 & 0,1464 & 10,5 & 0,1321 & 11,0 \\
\hline $8 \mathrm{~b}$ & $P_{\mathrm{fc}}$ & $\mathrm{kW}$ & 0,1972 & 14,1 & 0,1895 & 13,5 & 0,1828 & 13,1 & 0,1601 & 13,3 \\
\hline 9 & $C_{\mathrm{D}}$ & & \multicolumn{2}{|c|}{11,98} & \multicolumn{2}{|c|}{5,13} & \multicolumn{2}{|c|}{3,06} & \multicolumn{2}{|c|}{1,05} \\
\hline 10 & $\eta_{\mathrm{I}}$ & $\%$ & \multicolumn{2}{|c|}{16,06} & \multicolumn{2}{|c|}{20,41} & \multicolumn{2}{|c|}{23,34} & \multicolumn{2}{|c|}{29,09} \\
\hline
\end{tabular}

\section{Conclusions}

In this study, an energy analysis of an induction fluid heater with five inducer discs that has been developed to produce dry and hot air was performed. The results of the analysis lead to the possibility of increasing the thermal efficiency of the system.

It was determined that the discs adversely affect the thermal efficiency of the system. The thermal efficiency of the system could be increased from $16,06 \%$ to 29,09 $\%$ by removing the discs. Additionally it is defined that the efficiency of the system can be boosted up to $24,4 \%$ by recovering radiation and natural convection losses by appropriate insulation and up to $29,9 \%$ by recovering discharge losses by selecting an appropriate geometry.

To avoid the losses due to kinetic energy variation, a correlation was obtained between the target temperature difference and the cross-sectional diameter ratios at the inlet and outlet. Designing the system according to this correlation may result in an improvement in the thermal efficiency by $9,9 \%$. It was calculated that the thermal efficiency of the system could be boosted up to $90 \%$ or over with the recommendations that are given in this study.

For further studies, the effect of designing the $D_{\mathrm{i}} / D_{\mathrm{o}}$ ratio smaller than the recommendation given in this study should be analysed. With the further analysis, it is expected to see whether the reduction of the kinetic energy is added to the thermal efficiency or entropy generation and how much the efficiency enhancement can be obtained.

\section{Acknowledgements}

This study was granted by Yalova University Applied Research Center and Scientific Research Unit (BAP) with the project number of $013 / \mathrm{BAP} / 070$. I also gratefully thank Mr. I. Muzaffer ÜNVER, Prof. Dr. Fikret YUKSEL, Prof. Dr. Omer KAYNAKLI and Mr. Lenny CRAGG for their valuable supports.

\section{References}

[1] Haimbaugh R. E. Practical Induction Heat Treating. ASM International, Ohio, 2001. DOI: 10.1361/piht2001

[2] Lucía, O.; Maussion, P.; Dede, E. J.; Burdío, J.M. Induction Heating Technology and Its Applications: Past Developments, Current Technology and Future Challenges. // IEEE Transactions on Industrial Electronics. 61, 5(2014), pp. 2509-2520. DOI: 10.1109/TIE.2013.2281162

[3] http://www.efd-induction.com/en/ /media/PDF/ Applications/Applications.ashx. last access: 21.01.2016

[4] Unver, H. M.; Aydemir, M. T.; Çelik, V. Power and Frequency Control in a $60 \mathrm{~kW}$ Induction Steel Heating Furnaces through PLC. // IEE Power Engineer. 19, 3(2005), pp. 36-39. DOI: 10.1049/pe:20050307

[5] Chandravanshi, V. K.; Bhattacharjee, A.; Kamat, S. V.; Nandy, T. K. Influence of thermomechanical processing and heat treatment on microstructure, tensile properties and fracture toughness of Ti-1100-0.1B alloy. // Journal of Alloys and Compounds. 589, 15(2014), pp. 336-345. DOI: 10.1016/j.jallcom.2013.11. 014

[6] Uzun, O.; Kilicaslan, M. F.; Yılmaz, F. Formation of novel flower-like silicon phases and evaluation of mechanical properties of hypereutectic melt-spun $\mathrm{Al}-20 \mathrm{Si}-5 \mathrm{Fe}$ alloys with addition of V. // Materials Science and Engineering: A. 607(2014), pp. 368-375. DOI: 10.1016/j.msea.2014.04.025

[7] Makimura, Y.; Tomita, H.; Motegi, S. Superheated steam generator by induction heating. // Power Electronics and Applications. EPE '09. 13th European Conference Barcelona, 8-10 Sept. 2009, pp. 1-4, E-ISBN: 978-9075815-13-9.

[8] Evaporators with Induction Heating and Their Applications. // Advances in Induction and Microwave Heating of Mineral and Organic Materials / Anatoly Kuzmichev and 
Leonid Tsybulsky. InTech Press, 2011. pp: 269-302. DOl: $10.5772 / 13934$

[9] Liu, Q.; Schlangen, E.; García, Á.; van de Ven, M. Induction heating of electrically conductive porous asphalt concrete. // Construction and Building Materials. 24(2010), pp. 1207-1213. DOI: 10.1016/j.conbuildmat.2009.12.019

[10] Bera, A.; Babadagli, T. Status of electromagnetic heating for enhanced heavy oil/bitumen recovery and future prospects: A review. // Applied Energy. 151, (2015), pp. 206-226. DOI: 10.1016/j.apenergy.2015.04.031

[11] Li, C.; Burke, N.; Gerdes, K.; Patel, J. The undiluted, noncatalytic partial oxidation of methane in a flow tube reactor -An experimental study using indirect induction heating. // Fuel. 109, (2013), pp. 409-416. DOl: 10.1016/j.fuel.2013.02.055

[12] Kenada, M.; Hishikawa, S.; Tanaka, T.; Guo, B.; Nakaoka, M. Innovative Electromagnetic Induction Eddy CurrentBased Dual Packs Heater Using Voltage-Fed HighFrequency PWM Resonant Inverter for Continuous Fluid Processing in Pipeline. // IEEE Engineering Technologies 1999; Vol: 2, pp. 797-802.

[13] Laohalertdecha, S.; Naphon, P.; Wongwises, S. A review of electrohydrodynamic enhancement of heat transfer. // Renewable and Sustainable Energy Reviews. 11, (2007), pp. 858-876. DOI: 10.1016/j.rser.2005.07.002

[14] Nakabori, T.; Ikeda, H.; Suzuki, T.; Yoshida, H.; Iwanabe, N.; Hattori, M. Dispersion of Water drops by Induction Heating Using MOS-FET Inverter. // Proceedings of the IECON 21st International Conference, Orlando USA 1995; Vol: 1, pp. 564-567. DOI: 10.1109/IECON.1995.483470

[15] Nakamizo, T.; Kenada, M.; Hishikawa, S.; Guo, B.; Iwamoto, H.; Nakaoka, M. New Generation Fluid Heating Appliance Using High Frequency Load Resonant Inverter. // IEEE 1999 International Conference on Power Electronics and Drive Systems, PEDS'99, Hong Kong, 1999; Vol. 1, pp. 309-314.

[16] Tanaka, H.; Kaneda, M.; Chandhaket, S.; Aubdallha, A. L. M.; Nakaoka, M. Eddy Current Dual Packs Heater based Continuous Pipeline Fluid Heating using Soft Switching PWM High Frequency Inverter. // ISIE'2000, Proceedings of the 2000 IEEE International Symposium Cholula, Puebla, Mexico, 4-8 Dec. 2000, pp. 306-311.

[17] Guo, B.; Okuno. A.; Iwamoto, H.; Gamage, L.; Koudriavtsev, O.; Hirakı, E.; Nakaoka, M. Latest electromagnetic induction-based fluid-heating appliance using voltage-source series loaded-resonant pulse-width modulation high-frequency inverter. // Int. J. Electronics. 86, 10(1999), pp. 1261-1279, DOI: 10.1080/002072199132798

[18] Development of Customized Solutions - an Interesting Challenge of Modern Induction Heating. // Advances in Induction and Microwave Heating of Mineral and Organic Materials / Jens-Uwe Mohring and Elmar Wrona. InTech Press, 2011. pp. 125-134. DOI: 10.5772/13841

[19] Use of Induction Heating in Plastic Injection Molding Industrial Induction. // Advances in Induction and Microwave Heating of Mineral and Organic Materials / Udo Hinzpeter and Elmar Wrona. InTech Press, 2011. pp. 339-344. DOI: $10.5772 / 13842$

[20] Sadakata, H.; Nakaoka, M.; Yamashita, H.; Omori, H.; Terai, H.; Developmentof Induction Heated Hot Water Producer Using Soft Switching PWM High Frequency Inverter. // IEEE PCC-Osaka-2002, pp. 452-455. DOI: 10.1109/PCC.2002.997560

[21] Popa, C.; Pentiuc, R. Analysis of a new induction thermal converter for heating. // Energy. 42, (2012), pp. 81-93. DOI: 10.1016/j.energy.2011.07.046

[22] Wang, S.; Izaki, K.; Hirota, I.; Yamashita, H.; Omori, H.; Nakaoka, M. Induction-Heated Cooking Appliance Using New Quasi-Resonant ZVS-PWM Inverter With Power Factor Correction. // IEEE Transactions on Industry
Applications. 34, 4(1998), pp. 705-712. DOl: 10.1109/28.703961

[23] Waeckerle, T.; Fraisse, H.; Boulogne, B.; Spire, S. L. New alloys and multilayer configuration of them to get selfregulated temperature cookware (SRTC) in induction heating. // Journal of Magnetism and Magnetic Materials. 304, (2006), pp. e844-e846. DOI: 10.1016/j.jmmm.2006.03.013

[24] Acero, J.; Carretero, C.; Millán, I.; Alonso, R.; Lucía, O.; Burdío, J. M. Experimental setup for inductive efficiency measurements of domestic induction systems based on energy balance. // IECON 2010 - 36th Annual Conference on IEEE Industrial Electronics Society, Glendale, AZ. 7-10 Nov. 2010, pp. 114-119. DOI: 10.1109/IECON.2010.5675191

[25] Cadavid, F. J.; Cadavid, Y.; Amell, A. A.; Arrieta, A. E.; Echavarría, J. D. Numerical and experimental methodology to measure the thermal efficiency of pots on electrical stoves. // Energy. 73, (2014), pp. 258-263. DOI: 10.1016/j.energy.2014.06.017

[26] Ahmed, T.; Ogura, K.; Chandhaket, S.; Nakaoka, M.; Asymmetrical Duty Cycle Controlled Edge Resonant Soft Switching High Frequency Inverter for Consumer Electromagnetic Induction Fluid Heater. // ATKAAF 44(12), (2003), pp. 21-26.

[27] Kurose, Y.; Hiraki, E.; Fukui, A.; Nakaoka, M. Phase Shifted ZVS-PWM High Frequency Load Resonant Inverter for Induction Heated Foam Metal Type Dual Packs Fluid Heater.// Industrial Electronics Society, 2003. IECON '03. The 29th Annual Conference of the IEEE Roanoke, VA, USA Vol: 2, pp. 1613-1616, 2-6 Nov. 2003 DOl: 10.1109/IECON.2003.1280299

[28] Kranjc, M.; Zupanic, A.; Miklavcic. D.; Jarm, T. Numerical analysis and thermographic investigation of induction heating. // International Journal of Heat and Mass Transfer. 53, (2010), pp. 3585-3591. DOI: 10.1016/j.jijheatmasstransfer.2010.04.030

[29] Numerical Modeling of Industrial Induction. // Advances in Induction and Microwave Heating of Mineral and Organic Materials / A. Bermúdez, D. Gómez, M. C. Muñiz, P. Salgado and R. Vázquez. InTech Press, 2011. pp: 75-100. DOI: $10.5772 / 13525$

[30] Shokouhmand, H.; Ghaffari, S. Thermal analysis of moving induction heating of a hollow cylinder with subsequent spray cooling: Effect of velocity, initial position of coil and geometry. // Applied Mathematical Modeling. 36, (2012), pp. 4304-4323. DOI: 10.1016/j.apm.2011.11.058

[31] Incropera, F. P.; DeWitt, D. P. Fundamentals of Heat and Mass Transfer. Fourth Edition, Wiley and Sons, New York, 1996.

[32] Cengel, Y. A.; Cimbala, J. M. Fluid Mechanics Fundamentals and Applications. (Translate from third edition: In Turkish) Palme Yayincilik, Ankara, 2015.

[33] Curran, J. S.; Featherstone, A. M. Electric-Induction Fluid Heaters. // Power Engineering Journal. 2, 3(1988), pp. 157160.

[34] Ploski, A.; Holmberg, S. Performance evaluation of radiant baseboards (skirtings) for room heating - An analytical and experimental approach. // Applied Thermal Engineering. 62, (2014), $\quad$ pp. 382-389. 10.1016/j.applthermaleng.2013.09.053

[35] Bekele, A.; Mishra, M.; Dutta, S.; Effects of Delta-Shaped Obstacles on the Thermal Performance of Solar Air Heater. // Advances in Mechanical Engineering,The Web version (2011). URL: http://ade.sagepub.com/content/3/ 103502.full.pdf + html 10.1155/2011/103502

(21.01.2016)

DOI:

[36] Di Luozzo, N.; Fontana, M.; Arcondo, B. Modeling of induction heating of carbon steel tubes: Mathematical analysis, numerical simulation and validation. // Journal of Alloys and Compounds. 536, S(2012), pp. 564-568. DOI: 10.1016/j.jallcom.2011.12.084 


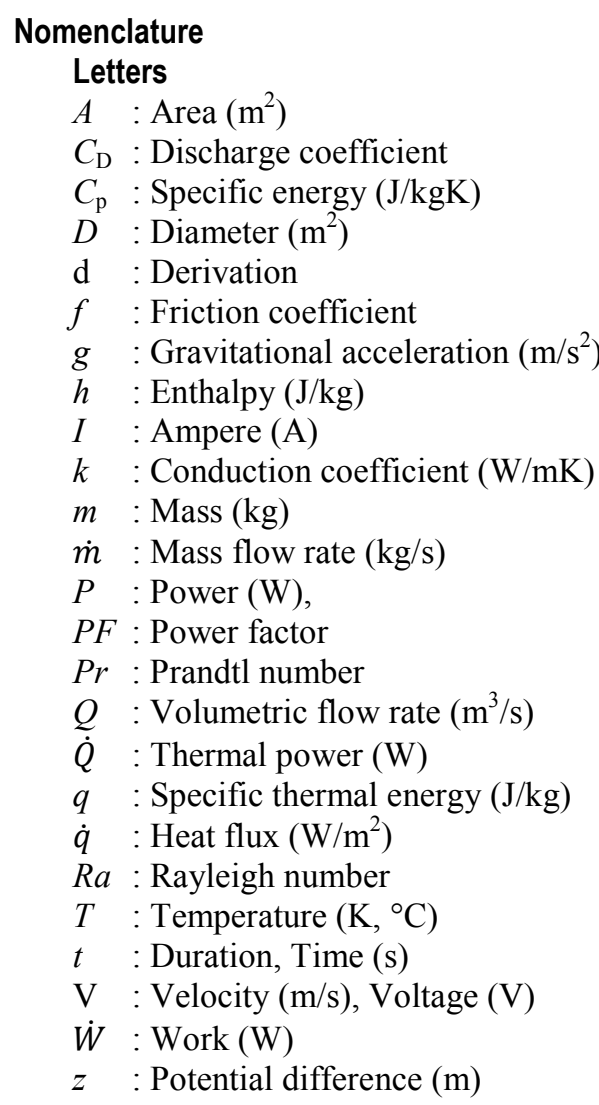

Sub-scripts

$\begin{array}{ll}\text { D } & : \text { Discharge } \\ \text { DL } & : \text { Loss due to discharge } \\ \text { el } & : \text { Electric } \\ \text { emp } & : \text { Empirical } \\ \text { exp } & : \text { Experimental } \\ \text { f } & : \text { Film temperature } \\ \text { fc } & : \text { Free convection } \\ \text { fl } & : \text { Fluid } \\ \text { gen } & : \text { Generation } \\ \text { ht } & : \text { Heat transfer } \\ \text { i } & : \text { Inlet } \\ \text { ind } & : \text { Induction } \\ \text { KE } & : \text { Kinetic energy } \\ \text { L } & : \text { Loss } \\ \text { m } & : \text { Mean } \\ \text { o } & : \text { Out, Exit } \\ \text { rad } & : \text { Radiation } \\ \text { S } & : \text { Lateral surface, Side } \\ \text { sh } & : \text { Shell } \\ \text { st } & : \text { Stored } \\ \text { T } & : \text { Top or bottom surface }\end{array}$

\section{Greek Letters and Symbols}

$\infty \quad$ : Environmental parameters

$\sum$ : Total, overall

$\Delta \quad$ : Difference

$\varepsilon \quad$ : Emissivity, negligible small

$$
\begin{aligned}
\rho & : \text { Density }\left(\mathrm{kg} / \mathrm{m}^{3}\right) \\
\sigma & : \text { Stephan-Boltzmann constant } \\
& 5,67 \times 10^{-8}\left(\mathrm{~W} / \mathrm{m}^{2} \mathrm{~K}^{4}\right) \\
\beta & : 1 / \text { Temperature }(1 / \mathrm{K}) \\
v & : \text { Kinematic viscosity }\left(\mathrm{m}^{2} / \mathrm{s}\right)
\end{aligned}
$$

\section{Author address}

Assist. Prof. Dr. Umit Unve University of Yalova, Faculty of Engineering, Energy Systems Engineering Department, 77100 Yalova Turkey

E-mail: umit.unver@yalova.edu.tr 